\title{
Prominent publications in cognitive psychology
}

\author{
MURRAY J. WHITE \\ Victoria University, Wellington, New Zealand
}

\begin{abstract}
This article identifies the 50 publications in cognitive psychology that were most frequently cited in the professional literature between 1979 and early 1982. The characteristics of these publications are discussed, and comparisons are made with other relevant findings.
\end{abstract}

Very few publications are frequently cited in the professional literature. About $25 \%$ of all scientific publications never get cited, and those that do average fewer than two citations a year. As far as the literature of cognitive psychology is concerned, there were 21 articles and books that received more than 20 citations a year between 1969 and 1977. A conservative estimate of 3,000 potentially citable publications means that more than $99 \%$ of these were cited fewer than 20 times a year (Garfield 1978a, 1978b, 1979). The bibliographies of undergraduate textbooks show a similar pattern of citation distributions. In a recent study of eight textbooks of human memory, I found references to just over 3,500 individual publications, of which $10(0.3 \%)$ were cited in all eight books and $2,800(81 \%)$ were cited in some one book (White, 1982). Subjective impressions of the literature converge on the point implicit in these findings: Many publications in cognitive psychology have little impact on the subject. For example, in a comprehensive review of memory and verbal learning research covering the period January 1967 to March 1969 , Tulving and Madigan (1970) selected a sample of 540 publications, representing slightly less than one-half of all relevant publications that had appeared during the period. They labeled $67 \%$ of this sample "utterly inconsequential," 25\% "run-of-the-mill" that will have "fallen into oblivion 10 years from now" (i.e., by 1980), and fewer than $10 \%$ as "worthwhile" (Tulving \& Madigan, 1970, pp. 441-442).

The least charitable interpretation one can put on these observations is to say that the effort expended by cognitive psychologists in the last 20 odd years has largely been wasted. Having said that, I should make it clear that the present article is intended neither as a polemic about the publish-or-perish controversy (perhaps it should be "publish-and-perish") nor as a contribution to the debate about the status of cognitive science (cf. Neisser, 1976; Newell, 1973; Tulving, 1979). Its purpose is to identify some of the publications that presently are having a weighty influence on the development of theory, research, and methodology in cognitive psychol-

The comments of Henry L. Roediger III on an earlier form of this article are gratefully acknowledged. The author's mailing address is: Department of Psychology, Victoria University, Private Bag, Wellington, New Zealand ogy. That such publications exist is evident from the foregoing observations. Whereas many contributions go uncited and unsung, there are some, however few in number, that are frequently cited and acknowledged; some of the effort has shown great rewards for cognitive psychology. This article provides a record of publications that are having a considerable impact on cognition research at the beginning of the 1980s; it uses the findings to establish the areas in cognitive psychology that now are carrying the burden of research activity; and it compares the findings with previous data to show what changes have occurred in research fronts.

The impact or importance of a publication can be gauged in at least three ways: through citations in the professional literature, through textbook citations, and through peer evaluations and ratings. The first of these measures is arguably the most objective, because it can use an accurate and detailed data base, the Social Science Citation Index (SSC). This shows, for any year, the frequency with which a publication has been cited in the world's scientific literature. All areas of psychololgy are covered, and all reputable psychology journals are indexed-well over 200 in the 1981 volume. The $S S C I$ is used here to develop a list of the 50 publications in cognitive psychology that were most frequently cited between 1979 and early 1982 . The number of 50 was chosen quite arbitrarily, with no a priori thought in mind that this would net all of the extant important publications.

\section{METHOD}

The $S S C I$ for $1979,1980,1981$, and the first quarter of 1982 (the latest available data) were searched for publications that appeared to be averaging more than 20 citations a year. In order to restrict the final list to publications that presently are having an influence on mainstream cognitive research, a publication also had to show a total of $\geqslant 5$ citations a year in any of the following journals: Cognition, Cognitive Psychology, Journal of Experimental Psychology: Human Memory and Learning, Journal of Experimental Psychology: Human Perception and Performance, Journal of Verbal Learning and Verbal Behavior, Memory \& Cognition, Psychological Review, and Quarterly Journal of Experimental Psychology.

\section{RESULTS}

The final list of 50 articles and books is shown in Table 1. This also shows the mean SSCI citation frequen- 
Table 1

Prominent Publications in Cognitive Psychology

Mean citations/

year in SSCI

Anderson, J. R. Language, memory and thought. Hillsdale, N.J: Erlbaum, 1976.

ANDE rson, J. R. Arguments concerning representations for mental imagery. Psychological Review, 1978, 85, 249-277.

Anderson, J. R., \& Bower, G. H. Human associative memory. Washington, D.C: Winston, 1973.

Atkinson, R. C., \& Shiffrin, R. M. Human memory: A proposed system and its control processes. In K. W. Spence \& J. T. Spence (Eds.), The psychology of learning and motivation: Advances in research and theory (Vol. 2). New York: Academic Press, 1968.

BADDELEY, A. D. The psychology of memory. New York: Harper \& Row, 1976.

BARTLETT, F. C. Remembering: $A$ study in experimental and social psychology. Cambridge: Cambridge University Press, 1932.

Battig, W. F., \& Montague, W. F. Category norms for verbal items in 56 categories: A replication and extension of the Connecticut category norms. Journal of Experimental Psychology Monograph, 1969, 80(3, Pt. 2).

Bransford, J. D., \& Franks, J. J. The abstraction of linguistic ideas. Cognitive Psychology, 1971, 2, 331-350.

Brondbent, D. E. Perception and communication. London: Pergamon, 1958.

Broadbent, D. E. Decision and stress. London: Academic Press, 1971.

Сномsкy, N. Aspects of the theory of syntax. Cambridge, Mass: M.I.T. Press, 1965.

Clark, H. H. The language-as-fixed-effect fallacy: A critique of language statistics in psychological research. Journal of Verbal Learning and Verbal Behavior, 1973, 12, 335-359.

Clark, H. H., \& Clark, E. V. Psychology and language: An introduction to psycholinguistics. New York: Harcourt Brace Jovanovich, 1977.

Collins, A. M., \& Loftus, E. F. A spreading-activation theory of semantic processing. Psychological Review, 1975, 82, 407-428.

Collins, A. M., \& Quillian, M. R. Retrieval time from semantic memory. Journal of Verbal Learning and Verbal Behavior, 1969, 8, 240-247.

Cratk, F. I. M., \& Lockhart, R. S. Levels of processing: A framework for memory research. Journal of Verbal Learning and Verbal Behavior, 1972, 11, 671-684.

Craik, F. I. M., \& Tulving, E. Depth of processing and the retention of words in episodic memory. Journal of Experimental Psychology: General, 1975, 104, 268-294.

Crowde r, R. G. Principles of learning and memory. Hillsdale, N.J: Erlbaum, 1976.

Fodor, J. A., Bever, T. G., \& GARRETt, M. F. The psychology of language. New York: McGraw-Hill, 1974.

JAMEs, W. The principles of psychology. New York: Holt, 1890.

Kahnemann, D. Attention and effort. Englewood Cliffs, N.J: Prentice-Hall, 1973.

Kintsch, W. The representation of meaning in memory. Hillsdale, N.J: Erlbaum, 1974.

Kintsch, W., \& VAN DiJK, T. A. Toward a model of text comprehension and production. Psychological Review, 1978, 85, 363-394.

KuČera, H., \& Francis, W. N. Computational analysis of present-day American English. Providence: Brown University Press, 1967.

Millen, G. A. The magical number seven, plus or minus two: Some limits on our capacity for processing information. Psychological Review, 1956, 63, 81-97.

Miller, G. A., Galanter, E., \& Pribram, K. H. Plans and the structure of behavior. New York: Holt, Rinehart \& Winston, 1960.

Minsky, M. A. A framework for representing knowledge. In P. H. Winston (Ed.), The psychology of computer vision. New York: McGraw-Hill, 1975.

NeI88E R, U. Cognitive psychology. New York: Appleton-Century-Crofts, 1967.

NeIsser, U. Cognition and reality: Principles and implications of cognitive psychology. San Francisco: Freeman, 1976.

Newelt, A., \& Simon, H. A. Human problem solving. Englewood Cliffs, N.J: Prentice Hall, 1972.

Norman, D. A., \& Bobrow, D. G. On data-limited and resource-limited processes. Cognitive Psychology, 1975, 7, 44-64.

Norman, D. A., \& Rumelhart, D. E. Explorations in cognition. San Francisco: Freeman, 1975.

Paivio, A. Imagery and verbal processes. New York: Holt, Rinehart \& Winston, 1971.

31

116

Paivio, A., Yuille, J. C., \& Madigan, S. A. Concreteness, imagery, and meaningfulness values for 925 nouns. Journal of Experimental Psychology Monograph, 1968, 76(1, Pt. 2).

Peterson, L. R., \& Peterson, M. J. Short-term retention of individual verbal items. Journal of Experimental Psychology, 1959, 58, 193-198. 
Table 1 continued

Prominent Publications in Cognitive Psychology

Publication

Mean citations/

year in SSCI

Posner, M. I., \& Snyder, C. R. R. Attention and cognitive control. In R. L. Solso (Ed.), Information processing and cognition: The Loyola Symposium. Hillsdale, N.J: Erlbaum, 1975.

PyLYSHYN, Z. W. What the mind's eye tells the mind's brain: A critique of mental imagery.

1979-1982

1971-1975* Psychological Bulletin, 1973, 80, 1-24.

Rosch, E. Cognitive representations of semantic categories. Journal of Experimental Psychology, 1975, 104, 192-233.

Rumelhart, D. E. Notes on a schema for stories. In D. G. Bobrow \& A. M. Collins (Eds.), Representation and understanding. New York: Academic Press, 1975.

Schneider, W., \& Shiffain, R. M. Controlled and automatic human information processing: I. Detection, search, and attention. Psychological Review, 1977, 84, 1-66.

Shiffrin, R. M., \& Schneiden, W. Controlled and automatic human information processing: II. Perceptual learning, automatic attending, and a general theory. Psychological Review, 1977, 84, 127-190.

Smith, E. E., Shoben, E. J., \& Rips, L. J. Structure and process in semantic memory: A featural model for semantic decisions. Psychological Review, 1974, 81, 214-241.

SPERLING, G. The information available in brief visual presentations. Psychological Monographs, 1960, 74(11, Whole No. 498).

Sternberg, S. High-speed scanning in human memory. Science, 1966, 153, 652-654.

Sternberg, S. Memory-scanning: Mental processes revealed by reaction-time experiments. American Scientist, 1969, 57, 421-457.

Thonndike, E. L., \& Longe, I. The teacher's word book of 30,000 words. New York: Teacher's College Press, Columbia University, 1944.

ThoRndyke, P. W. Cognitive structures in comprehension and memory of narrative stories. Cognitive Psychology, 1977, 9, 77-110.

Tulving, E. Episodic and semantic memory. In E. Tulving \& W. Donaldson (Eds.), Organization of memory. New York: Academic Press, 1972.

Tulving, E., \& Thomson, D. M. Encoding specificity and retrieval processes in episodic memory. Psychological Review, 1973, 80, 352-373.

Waugh, N. C., \& Norman, D. A. Primary memory. Psychological Review, 1965, 72, 89-104.
45

38

33

33

53

61

39

46

40

41

42

38

31

95

119

39

75

27

62

32

33

12
For publications dated 1973 or earlier.

cies (from all sources) for the period January 1979 to April 1982 and, for comparison, the corresponding rates for the period 1971 to 1975 inclusive. These latter rates are given only for publications dated 1973 or earlier, and in each case were based on citations for the years following the date of publication. The mean citation rate per year during the period $1979-1982$ for the 50 publications was 67 , the most-cited publication had a mean rate of 154 , and the least-cited publication a mean rate of 31. As a basis for comparison, it can be noted that articles published in Cognitive Psychology average about five citations a year, and those published in Psychological Review, about six citations a year.

\section{Ages of the Publications}

The watershed of modern cognitive psychology is often put at 1960, with the publications by Broadbent (1958), Chomsky (1957), Miller (1956), Miller, Galanter, and Pribram (1960). Peterson and Peterson (1959), and Sperling (1960) seen as powerful intellectual influences in determining subsequent developments. Only 8 of the 50 publications ( $16 \%$ ) carried pre-1961 dates; they were, with the exception of Chomsky's (1957) book, those listed above, together with Bartlett (1932), James (1890), and Thorndike and Lorge (1944). (Chomsky's, 1957, Syntactic Structures is still highly cited, but not in the central literature of cognitive psychology; it was cited a total of seven times in the eight selected journals during the period covered, compared with a mean total of 40 for the publications in Table 1. This might reflect a growing disenchantment among psychologists with syntactic theories in favor of theories about the representation of linguistic knowledge. Note, however, that Chomsky's, 1965, Aspects of the Theory of Syntax does appear in Table 1.) A majority of the articles and books ( 26 or $52 \%$ ) had publication dates of 1973 or later. The most recent publications were Anderson's (1978) paper on mental imagery and the paper by Kintsch and van Dijk (1978) on text comprehension. Overall, the re was no correlation between age of publication and frequency of citation.

\section{Publication Outlets}

In all sciences, the number of journal articles published each year exceeds by far the number of books. Social scientists are a peculiar breed in that they per- 
ceive books as the more important sources of archival material; in the natural and physical sciences the most highly cited publications are journal articles (Garfield, 1978b). Twenty-six (52\%) of the 50 publications in Table 1 were books or chapters in books, and these had a mean frequency of 80 citations a year. The 24 journal papers had a mean frequency of 53 citations a year. Seven of the eight most-cited publications were books, but Craik and Lockhart's (1972) article on levels of processing topped the list. With an average of 154 citations a year during the period, this undoubtedly has had the greatest influence of any single contribution published in the 1970s.

The 24 articles had appeared in 8 journals, 6 of which were psychology journals. Four journals accounted for 20 of the articles: Cognitive Psychology, Journal of Experimental Psychology, Journal of Verbal Learning and Verbal Behavior, and Psychological Review. This is an unusually small number, given that at least 30 international journals regularly publish articles about cognitive processes. At the same time, it is to be noted that these 4 journals are among the most prestigious in experimental psychology and that papers appearing in these journals have a better than even chance of being cited.

\section{Comparisons With Other Findings}

There were 29 publications dated 1973 or earlier and these had a mean citation rate of 50 between 1971 and 1975 and 79 between 1979 and 1982. Probably the single most important reason for this increase is the increasing domination of experimental psychology by research in cognition and memory. Although there appears to have been little change in the total number of journal articles in experimental psychology (the eight selected journals named in the Method section contained 438 articles in 1976 and 416 in 1981), the proportion of articles dealing with cognitive processes has increased. In short, as the number of relevant publications increases, so does the potential for citation. However, the correlation between the rates for 1979-1982 and 1971-1975 was +.60 , and only 4 of the 29 publications were cited less frequently in the later period. Three of these had to do with short-term memory (Peterson \& Peterson, 1959; Sternberg, 1966; Waugh \& Norman, 1965); the other was Thorndike and Lorge's (1944) word book.

Among the publications showing the greatest increase in citations, the publications by Bartlett (1932) and James (1890) are conspicuous by their age. Bartlett's Remembering averaged 36 citations a year between 1971 and 1975, and 116 between 1979 and 1982. The corresponding rates for James's Principles of Psychology were 49 and 124. The ideas of Bartlett, particularly those about schema and text comprehension, are now of principal concern to cognitive psychologists. James is cited frequently today because of his views on attention and consciousness and because of his prescience in distinguishing between primary memory and secondary mem- ory. In both cases, it was clear that many of the citations resulted from authors' feelings that due acknowledgment should be paid to these intellectual precursors of modern cognitive psychology, whether or not they (Bartlett and James) had directly inspired the research in which the citations were reported.

Reference has already been made to Garfield's listings of the 100 articles and 100 books most cited by social scientists between 1969 and 1977 (Garfield, 1978a, 1978b). Twelve of the 21 publications in cognitive psychology that featured in these listings (they also included works in education, sociology, statistics, economics, law, and philosophy) are shown in Table 1. They are: Broadbent (1958), Clark (1973), Craik and Lockhart (1972), Miller (1956), Miller et al. (1960), Neisser (1967), Paivio (1971), Peterson and Peterson (1959), Sperling (1960), Sternberg $(1966,1969)$, and Waugh and Norman (1965). Chomsky's (1965) Aspects of the Theory of Syntax can be added to this group. It cannot properly be described as a publication in cognitive psychology, but it is frequently cited in the mainstream literature of cognitive science. (Likewise, the publications by Kučera \& Francis, 1967, and Thorndike \& Lorge, 1944, are more accurately designated as important publications for cognitive psychology rather than as publications in cognitive psychology.) Eight papers that were among the 100 most cited between 1969 and 1977 are absent from Table 1. Three of these were in short-term memory, 2 in paired-associate learning, and 1 each in iconic memory, subjective organization, and long-term retrieval.

Another study that has been referred to is Tulving and Madigan's (1970) review of memory and verballearning research. Of the 187 publications cited by Tulving and Madigan, 5 (3\%) appear in Table 1: Atkinson and Shiffrin (1968), Broadbent (1958), Neisser (1967), Sternberg (1966), and Waugh and Norman (1965). It is to be recalled that Tulving and Madigan began with a sample of 540 publications, of which fewer than $10 \%$ were deemed "worthwhile" and likely to last the test of time.

In summary, these comparisons show that a fairly small number of publications have had a continuing and substantial impact on cognitive psychology during the past 12 years. The citation data point to a swing of interest away from verbal learning and the structural approach to memory research and toward semantic memory. Excluding review studies and textbooks, there are no publications in Table 1 that deal with associative interference theory and paired-associate learning, and the proportion of publications that deal with short-term memory is very much less than it was in the listings of Garfield (1978a, 1978b) and in the Tulving and Madigan (1970) review. Research about the representation of knowledge now prevails in cognitive psychology in that it constitutes the largest group of highly cited publications. 


\section{Research Areas}

Publications are cited for many reasons, and their influence can take several different forms. Some publications make notable contributions to theory and some to statistics and methodology, and some are known primar. ily for their scholarly analyses of the literature. A few publications have implications for a variety of research areas and are cited in the literature of different disciplines or of different areas making up a single science. Typically, however, an article or book "pulls in" most of its citations because of its contribution to a particular research area; most of its citations come from a fairly specific research literature. I assigned each of the 50 publications to one of several areas on the basis of its citation characteristics.

The first area comprised the representation of information in memory, including imagery and semantic memory, and the representation of linguistic knowledge. Eighteen of the publications appeared to be most frequently cited because of their contributions to this research. They were: Anderson (1976, 1978), Anderson and Bower (1973), Bartlett (1932), Bransford and Franks (1971), Collins and Loftus (1975), Collins and Quillian (1969), Kintsch (1974), Kintsch and vanDijk (1978), Minsky (1975), Norman and Rumelhart (1975), Paivio (1971), Pylyshyn (1973), Rosch (1975), Rumelhart (1975), Smith, Shoben, and Rips (1974), Thorndyke (1977), and Tulving (1972). Ten of these 18 publications had dates of 1974 or later.

A second area comprised research in the temporallystructured model of memory, retrieval from memory, and levels of processing. There were 12 publications here: Atkinson and Shiffrin (1968), Baddeley (1976), Craik and Lockhart (1972), Craik and Tulving (1975), Crowder (1976), James (1890), Miller (1956), Peterson and Peterson (1959), Sternberg (1966, 1969), Tulving and Thomson (1973), and Waugh and Norman (1965). A third area was attention and perceptual processing. The nine publications here were: Broadbent $(1958,1971)$, Kahnemann (1973), Neisser (1967), Norman and Bobrow (1975), Posner and Snyder (1975), Schneider and Shiffrin (1977), Shiffrin and Schneider (1977), and Sperling (1960). Seven of the 21 publications in these two latter groups had dates of 1974 or later.

The first three areas accounted for $75 \%$ of the publications listed in Table 1. With few exceptions, they were reports of theoretical models and appropriate empirical data. A fourth area could be defined in terms of methodological contribution. The five publications in this group were Clark's (1973) paper on the language-asfixed-effect fallacy, and the normative studies of Battig and Montague (1969), Kučra and Francis (1967), Paivio, Yuille, and Madigan (1968), and Thorndike and Lorge (1944). A fifth area comprised research in psycholinguistics. Excluding Chomsky's (1965) book, there were two publications here: Clark and Clark (1977) and Fodor, Bever, and Garrett (1974). Two publications were cited mainly for their contributions to problem solving, and this sixth area was represented by Miller et al.
(1960) and Newell and Simon (1972). Neisser's book (1976) Cognition and Reality did not easily fit into any one of these areas; perhaps the most appropriate would be the first one.

Clearly these sortings are not immutable. For example, it would not be stretching things to put Clark and Clark (1977), Fodor et al. (1974), Miller et al. (1960), and Newell and Simon (1972) in among the publications dealing with the representation of information in memory. Similarly, the books by Baddeley (1976), Crowder (1976), and Neisser (1967) deal with matters other than attention and short-term memory. But granting this, and the rather loose descriptions of research areas, a picture that is consistent with the previous findings emerges: The research having the greatest impact in cognitive psychology today is research in semantic memory.

\section{CONCLUSIONS}

Two concluding comments are in order. First, the article has dealt with highly cited publications and not with highly cited individuals. Many of the big names in cognitive psychology appear in Table 1 , but some do not. The reason is that although some people are presently having a considerable influence through their published contributions (their total works are averaging more than 100 citations a year-a figure exceeding that for some of the scholars named in Table 1), they do not have any one publication that satisfied the criteria adopted here. Second, the criteria themselves were arbitrary, and no implication is intended that a publication not listed in Table 1 is one of no importance to cognitive psychology. All that can reasonably be said is that the papers and books in Table 1 are among the most influential at the present time. Obviously, more liberal criteria would have resulted in a more extensive list, but any stricter criteria would not have added any new publications to those identified here.

\section{REFERENCES}

Сномsкy, N. Syntactic structures. The Hague: Mouton, 1957.

Garfield, E. The 100 articles most cited by social scientists, 1969-1977. Current Contents, August 7, 1978, 5-14. (a)

Garfield, E. The 100 books most cited by social scientists, 1969-1977. Current Contents, September 11, 1978, 5-16. (b)

Garfield, E. Citation indexing. New York: Wiley, 1979.

Ne ISSER, U. Cognition and reality. San Francisco: Freeman, 1976.

Newell, A. You can't play 20 questions with nature and win. In W. G. Chase (Ed.), Visual information processing. New York: Academic Press, 1973.

Social Science Citation Index. Philadelphia: Institute for Scientific Information, 1979-April 1982.

Tulving, E. Memory research: What kind of progress? In L.-G. Nilsson (Ed.), Perspectives on memory research. Hillsdale, N.J: Erlbaum, 1979.

Tulving, E., \& Madigan, S. A. Memory and verbal learning. In P. H. Mussen \& L. R. Rosenzweig (Eds.), Annual review of psychology. Palo Alto, Calif: Annual Reviews, 1970.

White, M. J. Are there that few memory publications worth remembering? Australian Psychologist, 1982, 17, 63-69.

(Manuscript received August 18, 1982; revisions accepted for publication March 24, 1983.) 